\title{
Detection of runoff timing changes in pluvial, nival, and glacial rivers of western Canada
}

\author{
Stephen J. Déry, ${ }^{1}$ K. Stahl, ${ }^{2,3}$ R. D. Moore, ${ }^{4}$ P. H. Whitfield, ${ }^{5}$ B. Menounos, ${ }^{6}$ \\ and Jason E. Burford ${ }^{1,7}$ \\ Received 6 March 2008; revised 29 January 2009; accepted 20 February 2009; published 25 April 2009.
}

[1] Changes in air temperature, precipitation, and, in some cases, glacial runoff affect the timing of river flow in watersheds of western Canada. We present a method to detect streamflow phase shifts in pluvial, nival, and glacial rivers. The Kendall-Theil robust lines yield monotonic trends in normalized sequent 5-day means of runoff in nine river basins of western Canada over the period 1960-2006. In comparison to trends in the timing of the date of annual peak flow and the center of volume, two other less robust metrics often used to infer streamflow timing changes, our approach reveals more detailed structure on the nature of these changes. For instance, our trend analyses reveal extension of the warm hydrological season in nival and glacial rivers of western Canada. This feature is marked by an earlier onset of the spring melt, decreases in summer streamflow, and a delay in the onset of enhanced autumn flows. Our method provides information on streamflow timing changes throughout the entire hydrological year, enhancing results from previous methods to assess climate change impacts on the hydrological cycle.

Citation: Déry, S. J., K. Stahl, R. D. Moore, P. H. Whitfield, B. Menounos, and J. E. Burford (2009), Detection of runoff timing changes in pluvial, nival, and glacial rivers of western Canada, Water Resour. Res., 45, W04426, doi:10.1029/2008WR006975.

\section{Introduction}

[2] Many rivers are fed by melting snow and glaciers [Barnett et al., 2005]. Projected increases in surface air temperatures over the next century will deplete seasonal and longer-term storage in these basins as snowpacks melt earlier and glaciers continue to retreat. Of particular concern is the earlier onset of the spring freshet and the reduction of streamflow during summer when human demand for this important resource peaks [Barnett et al., 2005].

[3] The annual streamflow hydrograph in snow and glacier-fed rivers is characterized by low flows during winter when water is stored in the seasonal snowpack and glaciers, and high flows during spring and summer when snow and glaciers melt. Shifts in the timing of spring high flows (freshets) can indicate changes in climate [Court, 1962]. For example, warm air temperatures in recent decades advanced the spring freshet in many snowmelt-fed rivers of North America [Whitfield and Cannon, 2000; Déry

\footnotetext{
${ }^{1}$ Environmental Science and Engineering Program, University of Northern British Columbia, Prince George, British Columbia, Canada.

${ }^{2}$ Department of Geosciences, University of Oslo, Oslo, Norway.

${ }^{3}$ Institute of Hydrology, University of Freiburg, Freiburg, Germany.

${ }^{4}$ Department of Geography, University of British Columbia, Vancouver, British Columbia, Canada.

${ }^{5}$ Environment Canada, Vancouver, British Columbia, Canada.

${ }^{6}$ Geography Program and Natural Resources and Environmental Studies Institute, University of Northern British Columbia, Prince George, British Columbia, Canada.

${ }^{7}$ Meteorological Service of Canada, Environment Canada, Dartmouth, Nova Scotia, Canada.

Copyright 2009 by the American Geophysical Union. 0043-1397/09/2008WR006975\$09.00
}

et al., 2005; Stewart et al., 2005; Hodgkins and Dudley, 2006; Maurer et al., 2007; Moore et al., 2007; Burn, 2008].

[4] Several methods exist to detect changes in the timing of streamflow [Court, 1962]. One method tracks the date of the annual peak flow associated with snowmelt. However, this procedure is problematic in smaller watersheds where the timing of the annual daily maximum discharge can be dominated by synoptic events (e.g., rain-on-snow events or warm spells) rather than longer-term changes in climate. The fraction of the total annual discharge occurring in a given month provides another measure of changes in streamflow timing; however, this technique may mask fluctuations that arise on shorter time scales $(<1$ month $)$ as well as in precipitation characteristics (amount, phase, and timing) [Leith and Whitfield, 1998]. Another approach evaluates the occurrence of the center of volume, or some other fraction, of the total annual discharge volume. Although straightforward, this approach may yield misleading results for the detection of changes in the timing of spring freshets in basins where increased late season precipitation and/or glacier melt substantially contributes to discharge. Furthermore, these methods may not be applicable to rain-dominated (pluvial) rivers where water storage in the seasonal snowpack or glaciers does not occur. Metrics of streamflow timing changes need to account for multiple runoff generating mechanisms and how these may affect the timing and quantity of runoff through time.

[5] We propose a reliable technique to detect changes in the timing of runoff that may be applied to rivers of varying hydrological regimes. This method assesses monotonic trends in time series of sequent 5-day means in runoff for pluvial, nival and glacial rivers of western Canada. We evaluate our approach against other metrics of streamflow 
Table 1. Coordinates and Identification Number of Gauges, Mean Basin Elevation, Gauged Area, Initial Year and Fraction of Data Availability, Hydrological Regime, and Glacier Coverage for Selected Rivers of Western Canada ${ }^{a}$

\begin{tabular}{|c|c|c|c|c|c|c|c|c|c|}
\hline $\begin{array}{l}\text { River } \\
\text { Basin }\end{array}$ & $\begin{array}{l}\text { Latitude } \\
(\text { deg N) }\end{array}$ & $\begin{array}{l}\text { Longitude } \\
\text { (deg W) }\end{array}$ & ID & $\begin{array}{l}\text { Elevation } \\
(\mathrm{m})\end{array}$ & $\begin{array}{c}\text { Area } \\
\left(\mathrm{km}^{2}\right)\end{array}$ & $\begin{array}{l}\text { Initial } \\
\text { Year }^{b}\end{array}$ & $\begin{array}{c}\text { Missing } \\
(\%)\end{array}$ & Regime & $\begin{array}{c}\text { Glaciers } \\
(\%)\end{array}$ \\
\hline Yakoun & 53.61 & 132.21 & 08OA002 & 356 & 477 & 1962 & 3.8 & $\mathrm{P}$ & 0 \\
\hline Zeballos & 50.01 & 126.84 & 08HE006 & 836 & 178 & 1960 & 1.1 & $\mathrm{P}$ & 0 \\
\hline San Juan & 48.57 & 124.30 & 08НA010 & 663 & 580 & 1960 & 7.7 & $\mathrm{P}$ & 0 \\
\hline Tuya & 58.07 & 130.82 & 08CD001 & 1316 & 3600 & 1962 & 3.8 & $\mathrm{~N}$ & 0 \\
\hline Little Swift & 52.92 & 121.76 & 08KE024 & 1583 & 127 & 1971 & 2.0 & $\mathrm{~N}$ & 0 \\
\hline Fishtrap & 51.12 & 120.21 & 08LB024 & 1388 & 135 & 1970 & 1.6 & $\mathrm{~N}$ & 0 \\
\hline Surprise & 56.11 & 129.47 & 08DA005 & 1400 & 221 & 1967 & 0.8 & G & 36 \\
\hline Doré & 53.31 & 120.24 & 08KA001 & 2002 & 409 & 1966 & 0.0 & G & 18 \\
\hline Lillooet & 50.33 & 122.79 & 08MG005 & 1678 & 2160 & $1960^{c}$ & 3.0 & G & 20 \\
\hline
\end{tabular}

${ }^{\mathrm{a}} \mathrm{P}$, pluvial; N, nival; G, glacial.

${ }^{\mathrm{b}}$ The final year of data availability is 2006 for all rivers.

cData from 1914 to 1959 are available but are not used in this study.

timing including trends in the date of peak flows and the center of volume. Furthermore, we apply the technique to other hydrometeorological variables (air temperature, precipitation, and snow accumulation) to better understand the forcing mechanism(s) for hydrological changes.

\section{Data and Methods}

[6] To demonstrate our approach we select nine rivers in western Canada (Table 1) for which mean daily discharge data are taken from the Water Survey of Canada (http:// www.wsc.ec.gc.ca/). The rivers typify pluvial, nival or glacial runoff regimes and comprise three transects across northern, central and southern British Columbia (BC). The initial year of data availability varies between gauges but all discharge time series end on 31 December 2006. The selected records are almost complete with less than $8 \%$ of the data missing in the worst case. After the initial year of data availability and where necessary, missing hydrological data for a given day are in filled by the mean daily values for that date over the period of record. River discharge data are then averaged over a 5-day period to obtain similar hydrological responses in both small and large watersheds. The use of sequent 5-day means also minimizes the effects of transient storms on precipitation fluctuations [Whitfield and Cannon, 2000]. Hydrographs are presented on a standard hydrological year (1 October to 30 September of the following year) and are referred to only by the year at which this cycle ends. In addition, runoff is normalized by basin area. Statistics including the mean and standard deviation in annual runoff are computed over the base period 19722006 for which hydrological data are available for all nine rivers of interest (Table 1).

[7] We normalize time series of river runoff by subtracting their mean and dividing by their standard deviation, computed over the period of data availability (Table 1). In addition, daily values are aggregated to sequent 5-day means $(\overline{5 d Q})$. Monotonic trends for each of the $73 \overline{5 d Q}$ time series are then calculated from the slope of the Kendall-Theil robust line [Theil, 1950]. The final year for all trend analyses remains fixed at 2006. The starting year, however, is varied to demonstrate its impact on the trend magnitudes. As described in section 3, this approach reveals runoff timing changes throughout the entire year whereas other methods focus on a single annual event or a specific month or season. For comparison, trends in the day of peak flow and in the center of volume of the total annual discharge based on daily data are also computed for each river [Court, 1962].

[8] In addition to trend magnitudes, studies often use the Mann-Kendall test (MKT) [Mann, 1945; Kendall, 1975; Lettenmaier et al., 1994; Déry and Wood, 2005; McClelland et al., 2006; Déry and Brown, 2007]. However, recent publications question the underlying assumptions of the hypotheses of such trend tests [Cohn and Lins, 2005; Koutsoyiannis and Montanari, 2007]. Indeed, there is an implicit assumption in the trend analyses that the underlying process behaves as an independent and identically distributed (IID) random variable or as an autoregressive (AR) process. Multiple studies demonstrate that streamflow does not typically behave as an IID or AR process, but instead tends to exhibit long-term persistence (LTP) and variability [e.g., von Storch, 1995; Fleming and Clarke, 2002; Matalas and Sankarasubramanian, 2003; Koutsoyiannis, 2003, 2006; Hamed, 2008]. Given the relatively short (3040 years) time series used for the trend analyses and the issues discussed above, we refrain from assigning a statistical significance to the results. Instead we focus on the magnitude of the trends in normalized units.

[9] Preliminary tests reveal minimal influence of serial correlation on the trend analyses. Lag 1 autocorrelations $\left(\rho_{1}\right)$ for the $\overline{5 d Q}$ time series computed for the period $1972-$ 2006 yield few instances when $\rho_{1}$ attains significance at $p<$ 0.05 (not shown). There are, however, two notable exceptions: Fishtrap Creek and the Tuya River show strong, positive autocorrelations during fall and winter, respectively. As demonstrated later, however, trends in $\overline{5 d Q}$ are not strong during these periods such that "prewhitening" of the time series is not conducted here [Yue et al., 2002]. In addition, only $3.5 \%$ of the $\overline{5 d Q}$ time series exhibit positive autocorrelations at $p<0.05$, a value well within the range that could be achieved by chance alone. Other tests reveal little (if any) impact of serial correlation on trends in the annual date of peak flows and in center of volume.

[10] The trend analyses of $\overline{5 d Q}$ time series then allow the "reconstruction" of annual hydrographs. Here the actual gauge-based measurements averaged for each 5-day period are replaced by the end points of the trend lines (or the Kendall-Theil robust lines). This step yields the reconstructed "initial" (1972) and "final" (2006) runoff values over the period for which the trend is computed [Déry et al., 2005]. This analysis allows the reconstruction of the annual 
Table 2. Summary of the Runoff Simulations ${ }^{\mathrm{a}}$

\begin{tabular}{lcccc}
\hline Run & $\begin{array}{c}\text { Mean } V_{0} \\
(\mathrm{~mm})\end{array}$ & $\begin{array}{c}\text { Trend } V_{0} \\
\left(\mathrm{~mm}(40 \mathrm{a})^{-1}\right)\end{array}$ & $\begin{array}{c}\text { Mean } t_{0} \\
(\text { days })\end{array}$ & $\begin{array}{c}\text { Trend } t_{0} \\
\left(\mathrm{~d}(40 \mathrm{a})^{-1}\right)\end{array}$ \\
\hline Base & 400 & 0 & 100 & 0 \\
V & 400 & -200 & 100 & 0 \\
T & 400 & 0 & 100 & -20 \\
VT & 400 & -200 & 100 & -20 \\
\hline
\end{tabular}

${ }^{\mathrm{a}}$ The base run has no trend in timing or volume; $\mathrm{V}$ has a trend in volume; $\mathrm{T}$ has a trend in timing; VT has a trend in both volume and timing.

hydrographs on the basis of the linear trends. These hydrographs then provide an illustration of the average structure of streamflow regime and timing changes at the beginning and end of the study period.

[11] In addition to the hydrological data, daily air temperature and precipitation measurements from Barkerville, $\mathrm{BC}$ are extracted from an online database (http://www. climate.weatheroffice.ec.gc.ca) to assess possible factors driving streamflow timing changes in the Little Swift River. This Environment Canada volunteer climate station is situated at $53.07^{\circ} \mathrm{N}, 121.50^{\circ} \mathrm{W}$ at $1265 \mathrm{~m}$ above sea level (a.s.l.). It is therefore just to the northeast of the Little Swift River Basin. While the quality of the record at Barkerville changes over time, observations were relatively consistent over the period of our study. Lag 1 autocorrelations of 5-day averages of air temperature and precipitation at Barkerville, $\mathrm{BC}$, over the period 1972-2006 do not attain $p<0.05$, minimizing the impact of serial correlation on these trend analyses. Daily snow water equivalent (SWE) data measured at a snow pillow at Barkerville by the BC Ministry of Environment, Water Stewardship Division (http://www.env. gov.bc.ca/rfc/), are also obtained to determine the possible role of a changing snowpack on the hydrology of the Little Swift River. This snow pillow is situated at $53.05^{\circ} \mathrm{N}$, $121.48^{\circ} \mathrm{W}$ at $1520 \mathrm{~m}$ a.s.1. The daily SWE time series begins in October 1968, but data are missing throughout the period 1989-1996. Monotonic trends for 5-day averages of normalized air temperature, precipitation and SWE data are evaluated to facilitate comparisons with the $\overline{5 d Q}$ trends. Note that the trend analysis for snow accumulation is performed only when the 5-day average exceeds $5 \mathrm{~mm}$ SWE such that no trends for this variable are available during summer.

\section{Proof of Concept}

[12] To explore how well the approaches characterize different types of hydrograph change, synthetic hydrographs for a nival regime are generated using a simple model that can incorporate trends in both the volume and timing of snowmelt. The model initially generates an annual time series of effective SWEs, representing the amount of snowmelt that becomes streamflow. The model does not explicitly account for evapotranspiration. The time series is specified by a mean and a trend magnitude. Similarly, a time series of the date of the onset of melt is generated using a mean and trend magnitude. For each year of simulation, meltwater generation is zero prior to the onset of melt. Once initiated, the melt for each day is computed as

$$
M(t, y)=k_{m}\left[t-t_{0}(y)\right] \times \frac{V(t, y)}{V_{0}(y)},
$$

where $M(t, y)(\mathrm{mm})$ is the melt generated on day $t$ in year $y, k_{m}\left(\mathrm{~mm} \mathrm{~d}^{-1}\right)$ is the rate at which melt increases through the melt season, $t_{0}(y)$ is the date of melt initiation in year $y$, $V(t, y)(\mathrm{mm})$ is the SWE on day $t$ and year $y$, and $V_{0}(y)$ $(\mathrm{mm})$ is the initial SWE in year $y$. The ratio $V(t, y) / V_{0}(y)$ represents in a crude manner the effect of decreasing snow cover area on basin melt through the freshet season. Each day, the SWE is updated by subtracting the day's melt:

$$
V(t, y)=V(t-1, y)-M(t, y) .
$$

[13] Routing of meltwater is accomplished by representing the catchment as a linear reservoir. Each day, the storage in the reservoir is updated by adding that day's melt:

$$
S(t, y)=S(t-1, y)+M(t, y) .
$$

Basin daily runoff, $Q(t, y)(\mathrm{mm})$, is then calculated as

$$
Q(t, y)=k_{r} S(t, y)
$$

where $k_{r}\left(\mathrm{~d}^{-1}\right)$ is a recession coefficient. The catchment storage is then updated by subtracting the runoff:

$$
S^{\prime}(t, y)=S(t, y)-Q(t, y)
$$

where the prime denotes an update to $S(t, y)$. In these tests, $k_{m}$ is set to $0.4 \mathrm{~mm} \mathrm{~d}^{-1}$ and $k_{r}$ is fixed at $0.02 \mathrm{~d}^{-1}$. These parameters are specified by trial and error to generate hydrographs that look as much as possible like real streamflow series. Four sets of simulations are run: (1) the base run has no trend in timing or volume; (2) the first scenario of a changing hydrological regime has a trend in volume $(\mathrm{V})$; (3) the second scenario has a trend in timing (T); and (4) the third scenario has a trend in both volume and timing (VT, Table 2).

[14] Diagrams of the idealized hydrographs and trends for the snowmelt-dominated river illustrate the potential utility of the method developed here (Figure 1). As expected, the first scenario (Figure 1a) reveals declining trends in daily streamflow throughout the entire hydrological year, with the largest decreases $\left(-2 \mathrm{~mm}(35 \mathrm{a})^{-1}\right)$ occurring in June and July. In the second scenario (Figure 1b), a couplet of moderate positive $\left(2 \mathrm{~mm}(35 \mathrm{a})^{-1}\right)$ then weak negative $\left(-1 \mathrm{~mm}(35 \mathrm{a})^{-1}\right)$ trends arises when the snowmelt shifts forward in time by 20 days. In the third scenario (Figure 1c), the trend analysis is marked by a similar positive/negative couplet, with weaker (stronger) $\overline{5 d Q}$ trends in April and May (June and July).

[15] Trends in the center of volume are also assessed for each of the three cases. Reducing the volume alone by nearly $50 \%$ advances the center of volume by 9 days. An earlier initiation of snowmelt (by 20 days) but keeping the overall volume fixed advances (by 17 days) the center of volume. In the final case, we see the additive effects of both a decline in volume (by nearly 50\%) and an advance (by 20 days) in the timing of snowmelt that lead to an earlier occurrence (by 26 days) in the center of volume.

[16] These tests demonstrate how changes in snowmelt volume alone can lead to spurious trends in the timing of the center of volume, even in the absence of a trend in the onset of melt. Our method clarifies the nature of the hydrological 

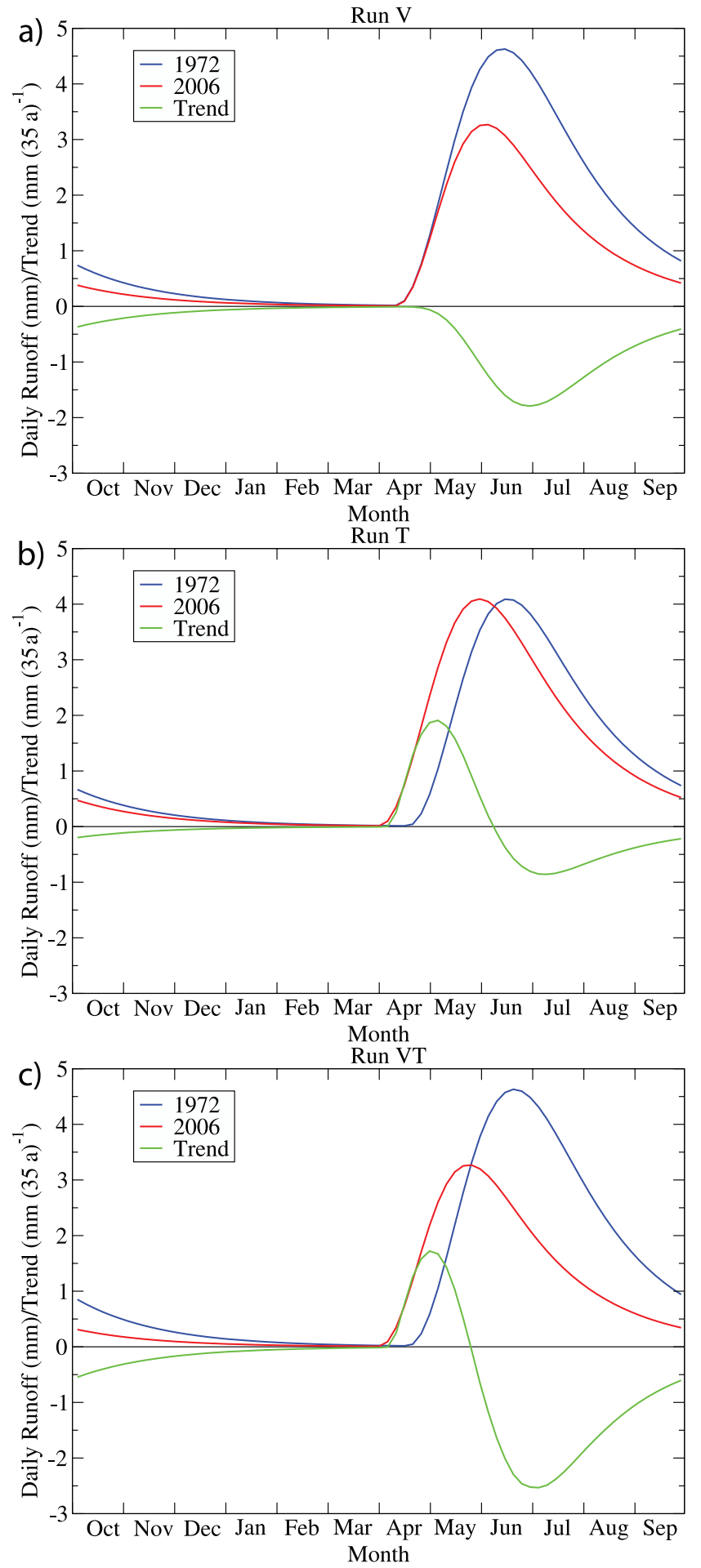

Figure 1. Original (1972), modified (2006), and trend (1972-2006) in the mean annual cycle of sequent 5-day mean river runoff for three different scenarios in a snowmelt-dominated basin (Table 2).

changes by providing trend information throughout the year. Integrating over time the $\overline{5 d Q}$ trends allows detection of changing amounts of river runoff on an annual or seasonal basis. Our technique then suggests the presence of streamflow phase shifts (rather than absolute trends) if the timeintegrated $\overline{5 d Q}$ trends approach zero, but individual values remain large and of the opposite sign (as in Figure 1b). In a case with changing annual volumes of runoff, our approach may also be applied to other hydrometeorological variables such as precipitation and snow accumulation to better understand the mechanism(s) driving hydrological phase shifts and trends.

\section{Results}

[17] The 1972-2006 mean annual runoff is low in snowdominated rivers, with an average of $399 \mathrm{~mm}$ in Fishtrap Creek and the Little Swift and Tuya rivers (Table 3). Mean annual runoff in pluvial and glacial rivers is high, with overall averages of 1837 and $1686 \mathrm{~mm}$, respectively. The variability, expressed by the standard deviation in annual river runoff, generally increases with mean annual runoff. The coefficient of variation in annual runoff ranges from 0.24 in nival rivers to 0.10 in glacial rivers, although this quantity is generally a function of glacier cover [Fountain and Tangborn, 1985; Moore, 1992]. The linear trend in mean annual runoff for the period 1972-2006 exhibits a relatively large, positive trend only for Surprise Creek.

[18] Runoff from pluvial, nival and glacial catchments differs in the timing and the quantity of flow (Figure 2). For example, flows in rain-dominated rivers in western Canada peak during fall and winter and are low during summer. In contrast, high flows in nival and glacial rivers occur in spring and summer with low flows during winter. Nival rivers show a more pronounced and narrower peak in river discharge driven by snowmelt, whereas glacial rivers have an extended period of high flows with an attenuated recession following snow and glacial melt. Accordingly, cumulative annual discharge rises more steadily in raindominated rivers than in nival or glacial rivers.

[19] The date of annual peak flow generally occurs in December in pluvial rivers and between May and August in nival and glacial rivers (Table 3). The mean date of annual daily maximum flow corresponds well to the date of center of volume in all rivers, with slightly larger disparities in pluvial and glacial rivers. The date of peak flow is less variable (standard deviation of 16 days) in nival rivers, a much lower value than observed in glacial (45 days) and pluvial (42 days) rivers. These differences reflect the fact that pluvial peak flows can be generated by rain events occurring through several months of the year (typically October to March), nival peak flows occur during the more constrained period of spring snowmelt (typically April to June), and peak flows in glacier-fed catchments normally occur during the spring-summer snowmelt period as well as the late summer period, when glacier melt can be important, and even occasionally during autumn-winter pineapple express events in coastal mountain catchments. The date of center of volume shows similar patterns but less overall variability than the date of peak flow. Over the period 1972-2006, there are notable earlier occurrences of the center of volume in all nival rivers and in the glacial Lillooet River.

[20] Trends in the date of peak flow are generally not strong (except for the San Juan and Tuya rivers) and differ considerably compared to trends in the date of center of volume (Figure 3). In nival and glacial rivers, the center of volume trends toward an earlier occurrence, with some noticeable trends in two thirds of these rivers when the 
Table 3. The 1972-2006 Annual Mean, Standard Deviation, and Trend of Runoff for 9 Rivers of Western Canada ${ }^{a}$

\begin{tabular}{|c|c|c|c|c|c|c|c|c|c|}
\hline \multirow[b]{2}{*}{ River Basin } & \multirow[b]{2}{*}{$\underset{(\mathrm{mm})}{Q}$} & \multirow[b]{2}{*}{$\begin{array}{c}\sigma \\
(\mathrm{mm})\end{array}$} & \multirow[b]{2}{*}{$\begin{array}{l}\text { Trend } \\
\left(\mathrm{mm} \mathrm{a}^{-1}\right)\end{array}$} & \multicolumn{3}{|c|}{ Date of Peak Flow } & \multicolumn{3}{|c|}{ Date of Center of Volume } \\
\hline & & & & $\begin{array}{l}\text { Mean } \\
\text { DOY }\end{array}$ & $\begin{array}{c}\sigma \\
\text { (days) }\end{array}$ & $\begin{array}{l}\text { Trend } \\
\left(\mathrm{d} \mathrm{a}^{-1}\right)\end{array}$ & $\begin{array}{l}\text { Mean } \\
\text { DOY }\end{array}$ & $\begin{array}{c}\sigma \\
\text { (days) }\end{array}$ & $\begin{array}{l}\text { Trend } \\
\left(\mathrm{d} \mathrm{a}^{-1}\right)\end{array}$ \\
\hline Yakoun & 1990 & 233 & -1.35 & 342 & 42.2 & 0.54 & 12 & 14.9 & -0.32 \\
\hline Zeballos & 911 & 140 & 2.27 & 352 & 48.7 & -0.13 & 35 & 23.5 & -0.57 \\
\hline San Juan & 2610 & 492 & -3.34 & 364 & 34.1 & 1.03 & 19 & 15.6 & -0.12 \\
\hline Tuya & 324 & 62 & -1.71 & 154 & 15.0 & -0.25 & 153 & 7.3 & -0.20 \\
\hline Little Swift & 692 & 136 & 1.30 & 148 & 20.9 & -0.14 & 147 & 11.2 & -0.54 \\
\hline Fishtrap & 181 & 60 & 0.96 & 130 & 12.4 & -0.31 & 135 & 9.5 & -0.35 \\
\hline Surprise & 2210 & 262 & 13.16 & 206 & 51.5 & -0.60 & 178 & 7.7 & -0.17 \\
\hline Doré & 1073 & 102 & 0.02 & 180 & 30.9 & -0.02 & 179 & 7.4 & -0.12 \\
\hline Lillooet & 1776 & 181 & 3.41 & 218 & 53.0 & -0.46 & 177 & 7.6 & -0.33 \\
\hline
\end{tabular}

${ }^{\mathrm{a}} Q$ is the annual mean and $\sigma$ is the standard deviation. Also listed are the $1972-2006$ means, standard deviations, and trends in the date of peak flow and center of volume for each river basin.

initial year for the analyses is in the 1960s and 1970s. For instance, the Lillooet River currently experiences an earlier occurrence (from 6 to 9 days) in the center of volume than in the 1970s.

[21] The center of volume is not a robust metric to assess streamflow timing changes. Changing the period over which the center of volume is computed, e.g., from the calendar to the hydrological year, can yield substantially different results, as is the case for the Little Swift River over the period 1972-2006 (Figure 4a). Although negative phase shifts in the date of the center of volume are inferred in both cases from the Kendall-Theil robust lines, the slope $(m)$ of the trend line is greater (in absolute terms) when based on the hydrological year $\left(m=-0.54 \mathrm{~d} \mathrm{a}^{-1}\right)$ compared to the calendar year $\left(m=-0.34 \mathrm{~d} \mathrm{a}^{-1}\right)$. In both cases, serial correlation influences the results to about the same degree with $\rho_{1}=0.33(p=0.06)$ and $0.31(p=0.08)$ for the results based on the hydrological and calendar years, respectively. Thus, choosing an initial date of 1 October rather than 1 January yields a difference of one week in the 35-year trend analysis on the occurrence of this event.
[22] Changes in the annual hydrograph illustrate the conditions leading to these results (Figure 4b). On average, the first half of the study period (1972-1988) exhibits more pronounced and later spring freshets than the latter half period. However, in the latter half period (1989-2006), there are relatively large increases in runoff from October to December that lead to the apparent phase shift toward an earlier timing in the center of volume. When relying on the calendar year, the higher October-to-December flows yield a delay in the center of volume, whereas on the basis of the hydrological year, they result in an advance of the center of volume. Thus, changes in the hydrological regime independent of the timing of the spring freshet influence the timing of the center of volume.

[23] An additional complication with the center of volume metric is that its timing is influenced by the total annual runoff (Figure 4c). For instance, an increase (decrease) in the accumulation of snow in the Little Swift River Basin may lead to an apparent shift toward a later (earlier) spring freshet, although the timing of the spring snowmelt itself may not have changed. These examples show two important

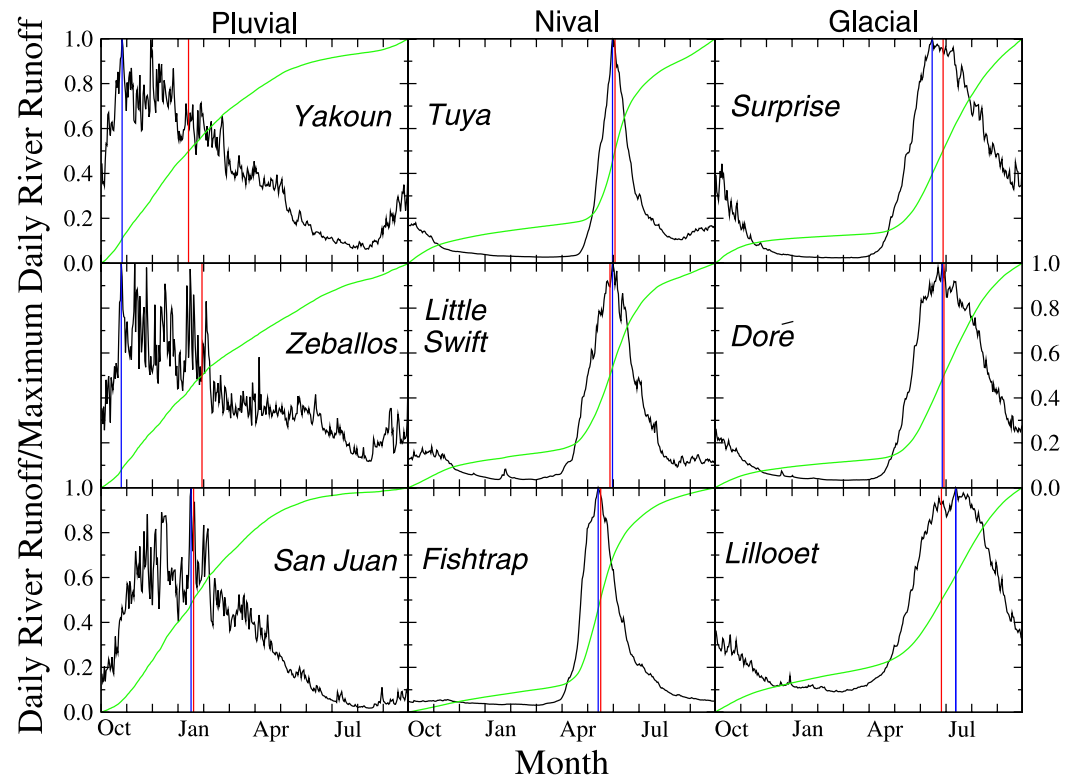

Figure 2. Mean annual cycle of daily normalized river runoff (black line) and cumulative runoff (green line) for nine rivers of western Canada. Also shown are the mean annual day of peak flow (blue line) and the center of volume (red line) based on the mean hydrograph. 


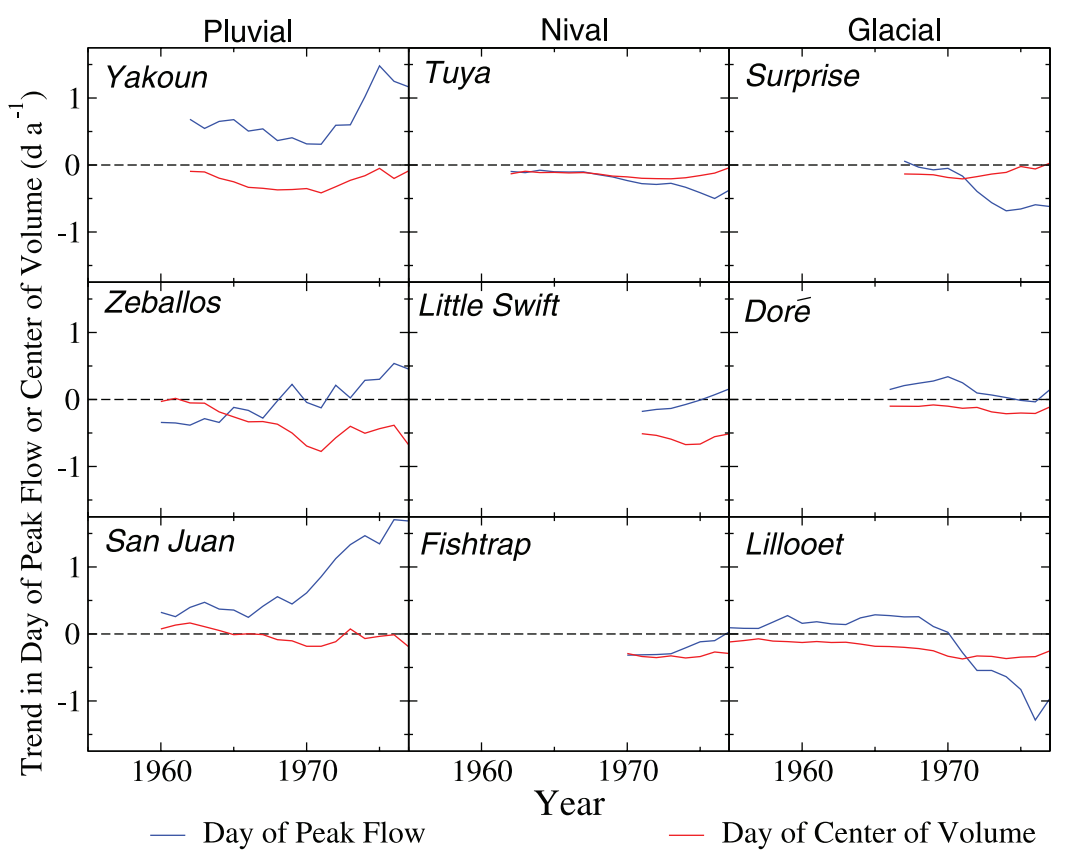

Figure 3. Trend in the day of peak flow and center of volume in discharge. Initial years for trends vary from 1960 to 1977 , and final year is 2006 .

limitations of the use of the center of volume to detect streamflow timing changes.

[24] The trend analysis of $\overline{5 d Q}$ time series is superior to the results obtained by other methods to detect streamflow timing changes (Figure 5). Strong, positive (negative) trends in runoff are generally observed during winter (summer) in pluvial rivers. For example, the Yakoun River runoff increases in late November and early December and decreases from April to June. Note however the marked change in the magnitude of the trends near 1975. Patterns for the pluvial Zeballos and San Juan rivers are similar but weaker than in the Yakoun River. On the other hand, large positive trends in runoff exist during spring in nival and glacial rivers, followed by strong negative trends during summer. These trends are well illustrated in the Doré River, with increasing runoff from January to early May and then decreasing runoff in late May to July. The positive/negative couplets in $\overline{5 d Q}$ trends observed in the Tuya, Little Swift, and Doré rivers suggest phase shifts toward earlier spring freshets (see section 3 ). The longer records of the Lillooet River show increasing runoff from November to January beginning in the late 1960s, whereas trends in other seasons remain relatively constant over time. In contrast to other nival and glacial rivers of western Canada, Surprise Creek shows pronounced positive trends in discharge throughout the summer.

[25] Figure 6 illustrates the transition of the hydrographs over time from their "initial" (1972) to "final" (2006) state on the basis of the Kendall-Theil robust lines. These reconstructed hydrographs reveal interesting trends including some notable reductions in runoff during spring in pluvial rivers (e.g., in the Yakoun and Zeballos rivers). There are also pronounced advances in the spring freshet in all nival rivers, as well as overall summer increases in runoff in Surprise Creek and decreases for the Doré and Lillooet rivers. A decline of $62 \mathrm{~mm} \mathrm{a}^{-1}$ from 1972 to 2006 during the spring freshet (2 April to 2 July) in the Little Swift River is compensated by positive trends during winter that lead to an overall increase in the annual runoff (Table 3 ). In contrast, increases of 12 and $20 \mathrm{~mm} \mathrm{a}^{-1}$ in runoff over the same 35-year period accompany the shifts in the spring freshets in the Tuya River and Fishtrap Creek, respectively.

[26] To better understand the factors driving the observed changes in runoff, we use a similar method on air temperature, precipitation and snow accumulation records from Barkerville, BC (Figure 7). In the Little Swift River Basin, enhanced precipitation as rain during October and November coincides with increasing runoff. Trends toward drier conditions accompany both rising air temperatures in December and early January and then cooling air temperatures in February, resulting in a decrease in snowpack accumulation. In May, there are moderate rises in air temperature that coincide with the advancing spring freshet; however, there is little trend in precipitation at this time. Despite the lack of consistency in air temperature and precipitation trends, these results suggest that reduced snow accumulation and higher air temperatures during spring, among other factors, are contributing to the advancing spring freshet in the Little Swift River.

\section{Discussion}

[27] Detection of a trend toward earlier spring freshets in snow-dominated rivers of western Canada is consistent with earlier studies that examined runoff in western North America [Whitfield and Cannon, 2000; Stewart et al., 2005; Regonda et al., 2005; Rood et al., 2008]. The trends in $\overline{5 d Q}$ provide a detailed assessment of these changes (Figure 5). When compared to other studies based on the timing of the center of volume, for example, enhanced discharge during April was followed by a decline in discharge during June in the Tuya River, indicative of a 


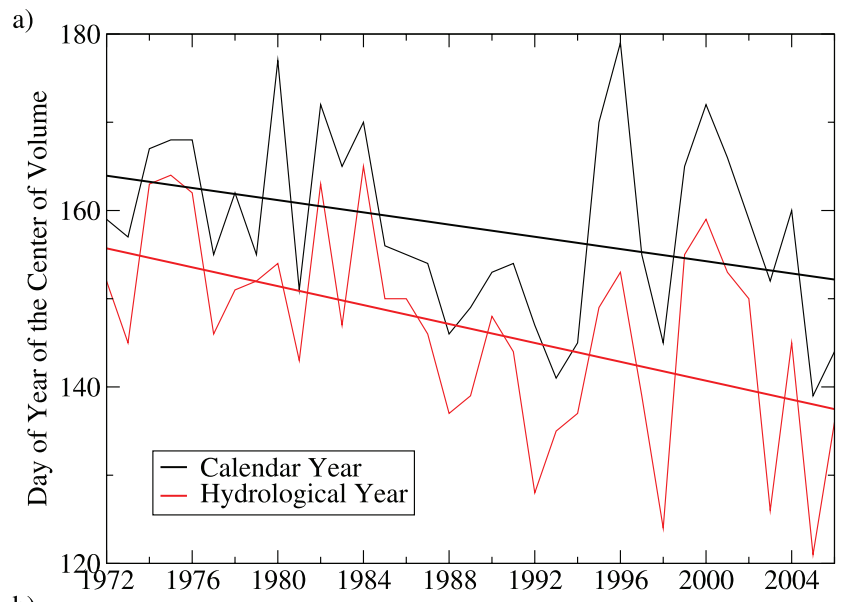

b)
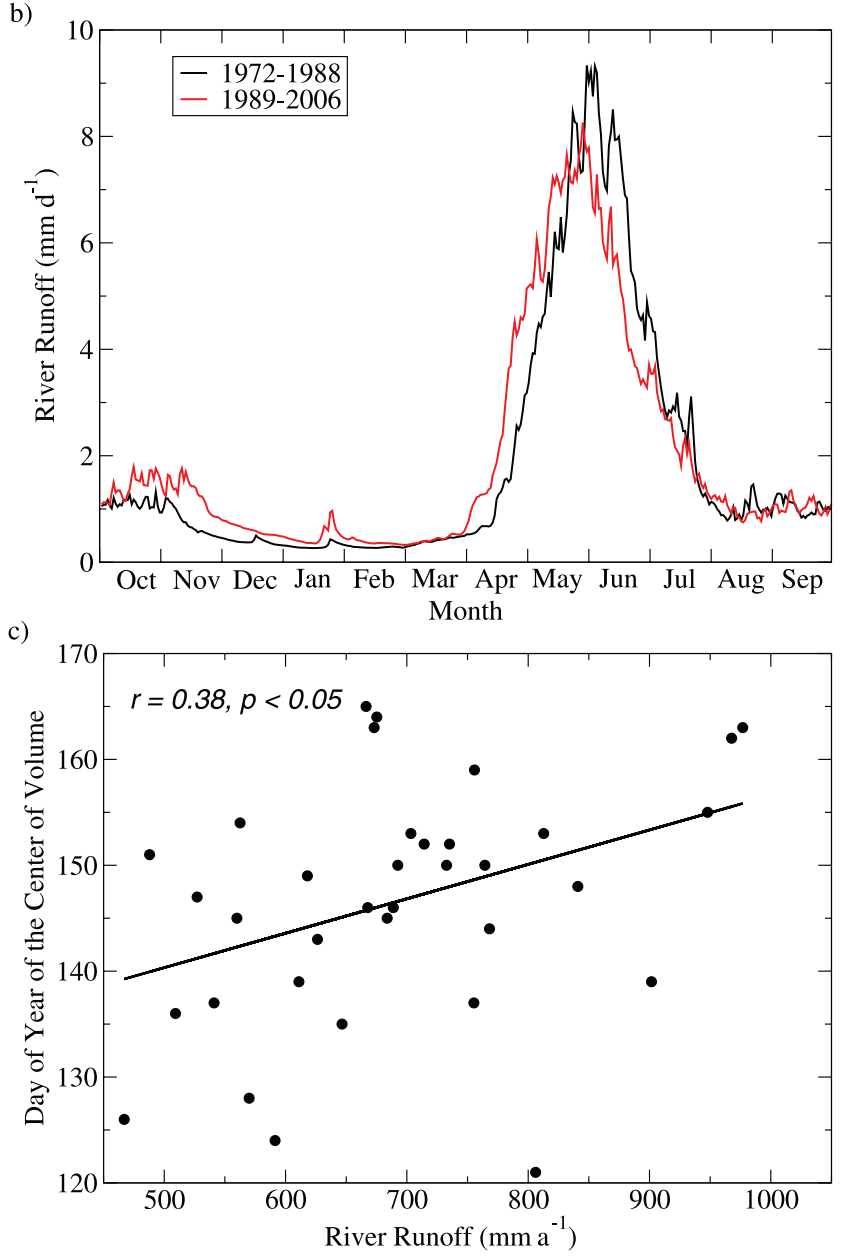

Figure 4. (a) The day of year of the center of volume based on the calendar and hydrological years in the Little Swift River, 1972-2006. Thick lines denote the KendallTheil robust lines. (b) Mean annual cycle of daily runoff in the Little Swift River for 1972-1988 and 1989-2006. (c) The day of year of the center of volume versus total annual runoff in the Little Swift River, 1972-2006. The thick line denotes the linear regression.

trend toward an earlier spring freshet. An earlier spring freshet and a delay in the storage of water in the ice and snowpacks in early fall is common to all nival and glacial rivers with the exception of Surprise Creek. Hence there is an extension of the warm hydrological season that is marked by relatively large reductions in summer runoff in these rivers. Similarly, there is a contraction of the cold hydrological season during which there are increases in river discharge in most nival and glacial basins.

[28] In contrast to its counterparts, summer runoff from Surprise Creek increased through time. This result is consistent with prior work that revealed August runoff in some glacier-fed basins of northwestern BC increased in recent decades [Fleming and Clarke, 2003; Stahl and Moore, 2006]. The positive trends probably relate to the fact that glacier mass loss in northwestern BC has been dominantly by downwasting over the period 1985-1999, rather than by terminal retreat [Schiefer et al., 2007; Moore et al., 2009]. Hence, warm air temperatures during spring produce an earlier onset of snowmelt and thus increases in spring streamflow. Earlier snowmelt and possibly higher rates of snowmelt during warmer summers would result in an early disappearance of snow and exposure of low-albedo firn and glacier ice, producing increased glacier melt and streamflow through summer. The detection of changes in runoff timing based on either the date of peak flow or the center of volume may therefore yield misleading or inconclusive results, especially in highly glacierized watersheds such as Surprise Creek.

[29] One benefit of our proposed method consists of its applicability to detect streamflow changes throughout the year to a broad range of hydrologic processes. For instance, trends in cold season low flows in nival and glacial rivers may be detected using this approach, which may be particularly important when assessing the potential contribution of base flow to river flows in basins underlain by permafrost. Permafrost thawing in high-latitude basins of North America and Eurasia may be contributing to increased cold season runoff [Whitfield and Cannon, 2000; Walvoord and Striegl, 2007; Smith et al., 2007; St. Jacques and Sauchyn, 2009]. Applying the trend analysis to daily or 5-day averages of discharge data from high-latitude or highaltitude rivers would provide critical information on the strength and nature of these changes.

[30] One complication of our proposed technique is whether the observed trends are driven primarily by the timing or the intensity of an event. For example, an increase (decrease) in snowpack conditions may lead to a more (less) intense spring freshet, even though the melt timing may not have changed [Moore et al., 2007]. However, performing the trend analysis to sequent 5-day averages of air temperature, precipitation and snow accumulation can help clarify the mechanisms driving changes in streamflow timing. For example, for the Little Swift River Basin, a combination of factors appears to have induced a shift in the spring freshet, including a decrease in snow accumulation during winter and rising air temperatures during spring. Future work will therefore focus on attributing regime changes in pluvial, nival and glacial rivers of western Canada.

[31] Applying the trend analysis to other hydrometeorological variables to infer the driving factors for change is particularly important in watersheds experiencing land cover modifications. Moore and Scott [2005, 2006] show that forest harvesting of almost $30 \%$ of the catchment of Camp Creek, located about $200 \mathrm{~km}$ south of Fishtrap Creek, significantly advanced the timing of snowmelt. Forest 

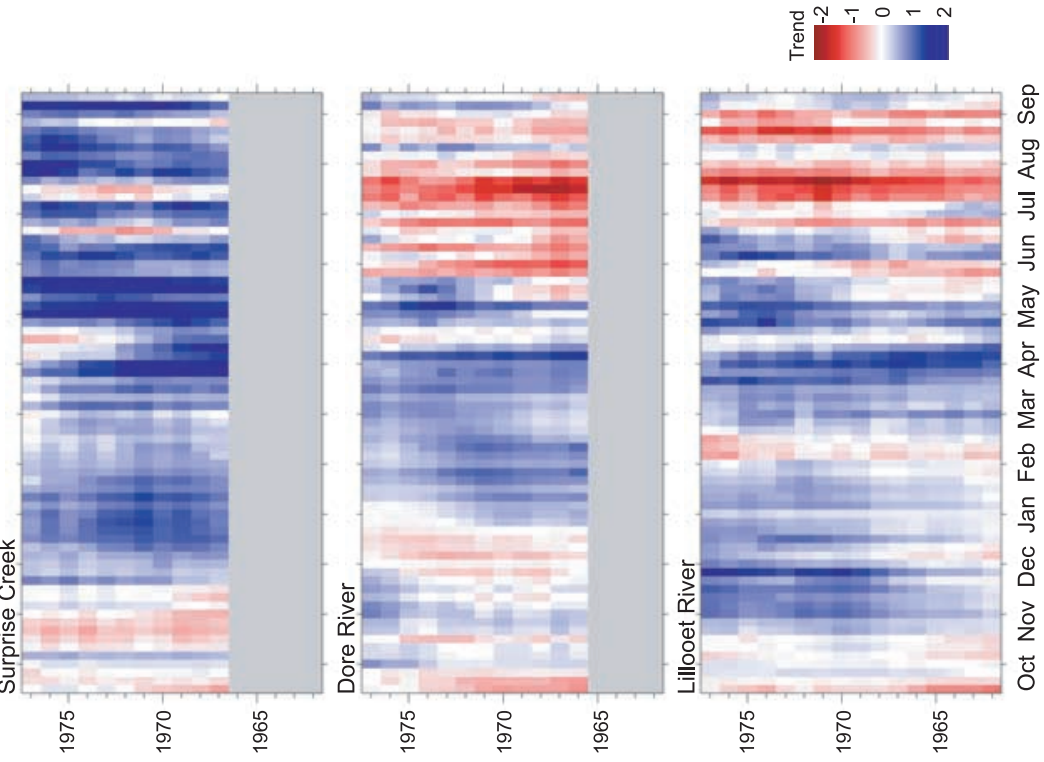

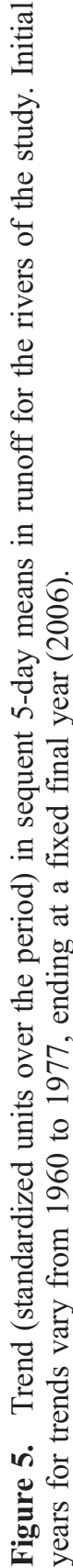
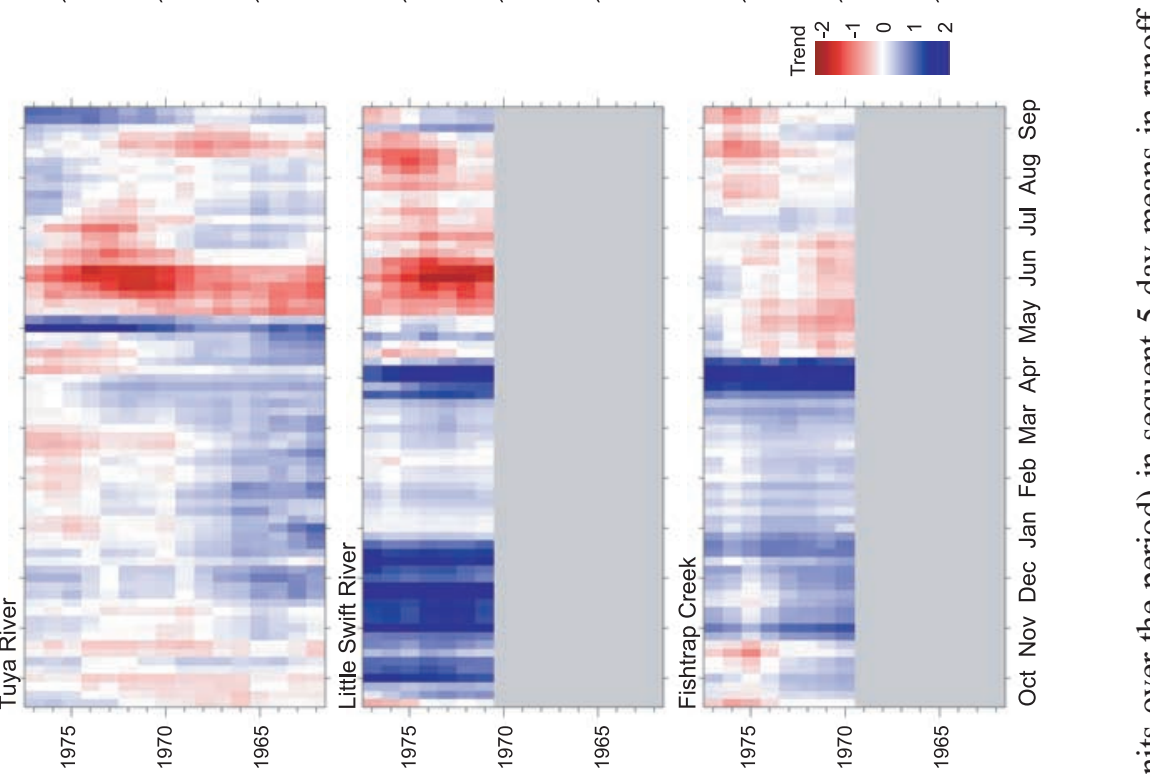


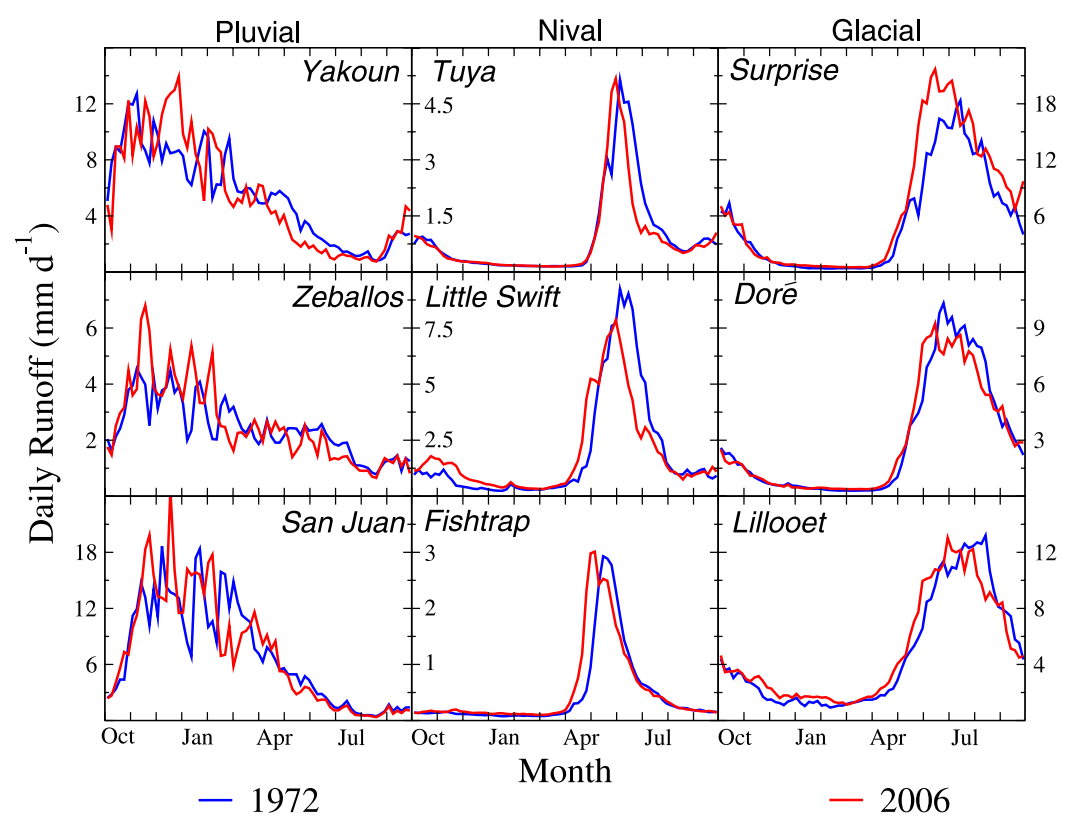

Figure 6. Initial (1972) and final (2006) annual hydrographs reconstructed from the end points of the Kendall-Theil robust lines.

harvesting has occurred in several of the basins considered here during the period of study, and a fire in 2003 affected $70 \%$ of Fishtrap Creek's catchment area. Therefore, the effects of spring warming on the advance of melt could be exaggerated. An important task is the development of approaches for disentangling the effects of climatic variability and change from the effects of land cover change.

[32] Long-term climatic variability associated with the observed shift in 1976/1977 of the Pacific Decadal Oscillation (PDO) led to dramatic changes in the climate of western North America [Mantua et al., 1997]. The PDO regime change forced a reversal of trends in air temperature across most of Alaska [Hartmann and Wendler, 2005]. The shift in the phase of the PDO may also influence trends in the amounts and timing of runoff in western Canada [Woo et al., 2006; Woo and Thorne, 2008]. There is some evidence of this with a transition in the strength of the runoff trends in $\approx 1975$ for the Yakoun River (Figure 5). Given the relatively short period of analysis examined in this study, however, it is difficult to assess whether the streamflow timing changes are part of a long-term, persistent trend or are associated in part with this climate shift. Extending the trend analyses by a decade to an initial year of 1986 yields similar patterns in the hydrographs to those obtained using an earlier period. Despite these preliminary findings, an extended period of study is required to better understand the impacts of climate variability and change on the timing of runoff in western Canada.

[33] The lag-1 autocorrelation considered here would result from basin storage that causes a year-to-year memory. If significant, it could be detected and corrected for, for instance, by prewhitening. The long-term persistence, however, relates to decadal or longer-scale climatic fluctuations. Our records are too short to detect and consequently correct for it. So the error we may make is to interpret something as a trend, which may in fact be part of a periodic behavior. For this analysis this distinction is secondary as the main
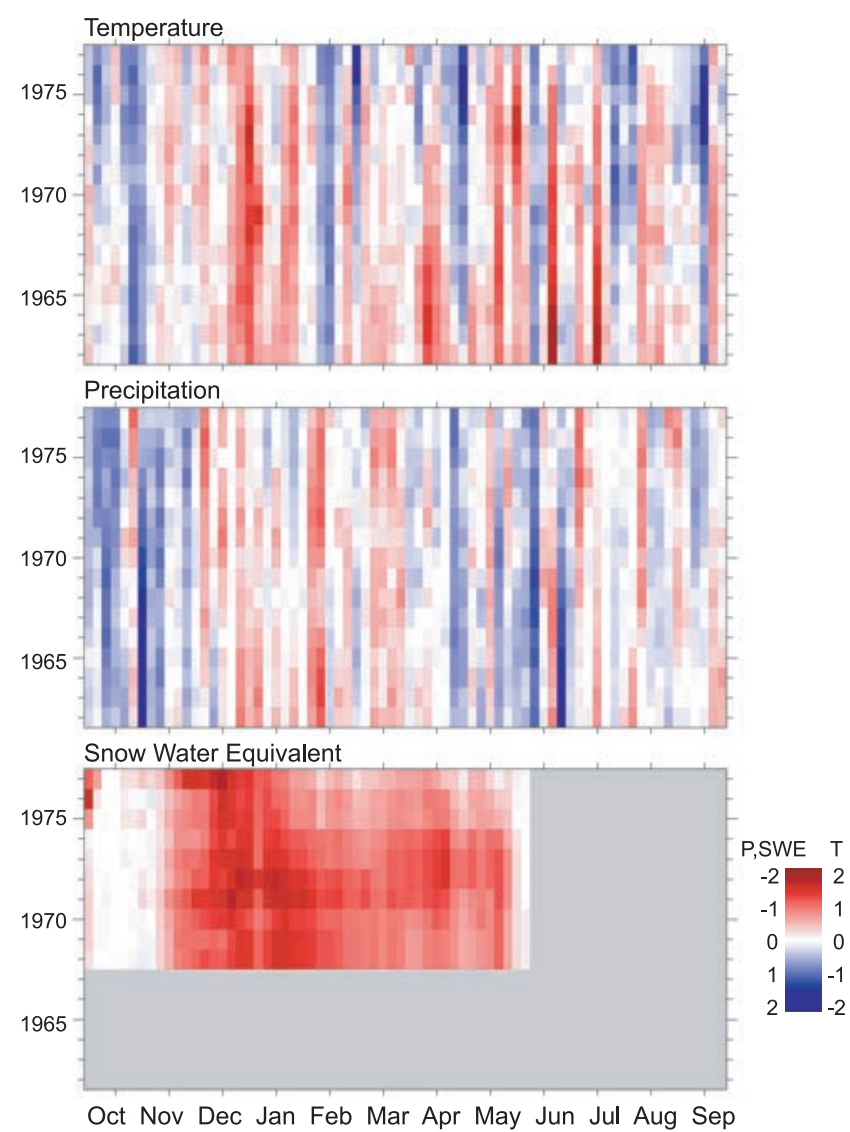

Figure 7. Trend (standardized units over the period) in sequent 5-day means of air temperature $(\mathrm{T})$, precipitation (P) and snow water equivalent (SWE) at Barkerville, British Columbia. Initial years for trends vary from 1960 to 1977 , ending at a fixed final year (2006). 
objective is the characterization of the relatively short term variability or covariability of hydrological and meteorological variables.

\section{Conclusion}

[34] Several studies project amplified warming during the 21 st century in mountainous regions such as the American Cordillera compared to low-lying areas [e.g., Bradley et al., 2004]. This amplified warming would have important ramifications for snowpack and glacier storage as well as for the distribution and phase of precipitation [Barnett et al., 2005; Déry and Wood, 2006]. Hence glacierized watersheds of North America may become climate change "hot spots" that would reveal substantial changes in air temperature and/ or precipitation that are manifested as changes in the seasonality of runoff. Hydrological monitoring thus requires reliable metrics to detect the impacts of climate change on streamflow timing. In addition, extended monitoring periods ( $>35$ years) may provide critical information on the relative impacts of climate variability and climate change on the timing of river runoff.

[35] Assessing phase shifts in river runoff using either the day of occurrence of the annual peak flow or the center of volume may lead to inconclusive or misleading results since these metrics depend on record length, seasonality of runoff, and interannual to interdecadal variability in runoff magnitude. Our method addresses some of these limitations and can detect streamflow timing changes in pluvial, nival and glacial rivers of western Canada. The technique is insensitive to the hydrological regime and it also provides detailed information on the temporal structure of the streamflow changes.

[36] Acknowledgments. We thank R. Allen (UNBC), B. Fast, and F. Weber (BC Hydro) for their assistance with this work. The paper greatly benefited from comments provided by J. Sheffield (Princeton), the associate editor D. Koutsoyiannis (National Technical University of Athens), H. Lins (USGS), P. Furcolo (Università degli Studi di Salerno), and two anonymous reviewers. Financial support from the Canadian Foundation for Climate and Atmospheric Sciences through the Western Canadian Cryospheric Network is gratefully acknowledged.

\section{References}

Barnett, T. P., J. C. Adam, and D. P. Lettenmaier (2005), Potential impacts of a warming climate on water availability in snow-dominated regions, Nature, 438, 303-309.

Bradley, R. S., F. T. Keimig, and H. F. Diaz (2004), Projected temperature changes along the American cordillera and the planned GCOS network, Geophys. Res. Lett., 31, L16210, doi:10.1029/2004GL020229.

Burn, D. H. (2008), Climatic influences on streamflow timing in the headwaters of the Mackenzie River Basin, J. Hydrol., 352, 225-238.

Cohn, T. A., and H. F. Lins (2005), Nature's style: Naturally trendy, Geophys. Res. Lett., 32, L23402, doi:10.1029/2005GL024476.

Court, A. (1962), Measures of streamflow timing, J. Geophys. Res., 67, $4335-4339$.

Déry, S. J., and R. D. Brown (2007), Recent Northern Hemisphere snow cover extent trends and implications for the snow-albedo feedback, Geophys. Res. Lett., 34, L22504, doi:10.1029/2007GL031474.

Déry, S. J., and E. F. Wood (2005), Decreasing river discharge in northern Canada, Geophys. Res. Lett., 32, L10401, doi:10.1029/2005GL022845.

Déry, S. J., and E. F. Wood (2006), Analysis of snow in the 20th and 21st century Geophysical Fluid Dynamics Laboratory coupled climate model simulations, J. Geophys. Res., 111, D19113, doi:10.1029/2005JD006920.

Déry, S. J., M. Stieglitz, E. C. McKenna, and E. F. Wood (2005), Characteristics and trends of river discharge into Hudson, James, and Ungava bays, 1964-2000, J. Clim., 18, 2540-2557.

Fleming, S. W., and G. K. C. Clarke (2002), Autoregressive noise, deserialization, and trend detection and quantification in annual river discharge time series, Can. Water Resour. J., 27(3), 335-354.
Fleming, S. W., and G. K. C. Clarke (2003), Glacial control of water resource and related environmental responses to climatic warming: Empirical analysis using historical streamflow data from northwestern Canada, Can. Water Resour. J., 28(1), 69-86.

Fountain, A. G., and W. V. Tangborn (1985), The effect of glaciers on stream flow variations, Water Resour. Res., 21, 579-586.

Hamed, K. H. (2008), Trend detection in hydrologic data: The MannKendall trend test under the scaling hypothesis, J. Hydrol., 349, 350363, doi:10.1016/j.jhydrol.2007.11.009.

Hartmann, B., and G. Wendler (2005), The significance of the 1976 Pacific climate shift in the climatology of Alaska, J. Clim., 18, 4824-4839.

Hodgkins, G. A., and R. W. Dudley (2006), Changes in the timing of winter-spring streamflows in eastern North America, 1913-2002, Geophys. Res. Lett., 33, L06402, doi:10.1029/2005GL025593.

Kendall, M. G. (1975), Rank Correlation Methods, 202 pp., Charles Griffin, London.

Koutsoyiannis, D. (2003), Climate change, the Hurst phenomenon, and hydrological statistics, Hydrol. Sci. J., 48, 3-24.

Koutsoyiannis, D. (2006), Nonstationarity versus scaling in hydrology, J. Hydrol., 324, 239-254.

Koutsoyiannis, D., and A. Montanari (2007), Statistical analysis of hydroclimatic time series: Uncertainty and insights, Water Resour. Res., 43, W05429, doi:10.1029/2006WR005592.

Leith, R. M. M., and P. H. Whitfield (1998), Evidence of climate change effects on the hydrology of streams in south-central B.C., Can. Water Resour. J., 23, 219-230.

Lettenmaier, D. P., E. F. Wood, and J. R. Wallis (1994), Hydroclimatological trends in the continental United States, 1948-1988, J. Clim., 7, $586-607$.

Mann, H. B. (1945), Non-parametric test against trend, Econometrika, 13, $245-259$.

Mantua, N., S. Hare, Y. Zhang, J. Wallace, and R. Francis (1997), A Pacific Interdecadal Climate Oscillation with impacts on salmon production, Bull. Am. Meteorol. Soc., 77, 437-471.

Matalas, N. C., and A. Sankarasubramanian (2003), Effect of persistence on trend detection via regression, Water Resour. Res., 39(12), 1342, doi:10.1029/2003WR002292.

Maurer, E. P., I. T. Stewart, C. Bonfils, P. B. Duffy, and D. Cayan (2007), Detection, attribution, and sensitivity of trends toward earlier streamflow in the Sierra Nevada, J. Geophys. Res., 112, D11118, doi:10.1029/ 2006JD008088.

McClelland, J. W., S. J. Déry, B. J. Peterson, R. M. Holmes, and E. F. Wood (2006), A pan-arctic evaluation of changes in river discharge during the latter half of the 20th century, Geophys. Res. Lett., 33, L06715, doi:10.1029/2006GL025753.

Moore, J. N., J. T. Harper, and M. C. Greenwood (2007), Significance of trends toward earlier snowmelt runoff, Columbia and Missouri Basin headwaters, western United States, Geophys. Res. Lett., 34, L16402, doi:10.1029/2007GL031022.

Moore, R. D. (1992), The influence of glacial cover on the variability of annual runoff, Coast Mountains, British Columbia, Canada, Can. Water Resour. J., 17, 101-109.

Moore, R. D., and D. F. Scott (2005), Camp Creek revisited: Streamflow changes following salvage harvesting in a medium-sized, snowmeltdominated catchment, Can. Water Resour. J., 30, 331-344.

Moore, R. D., and D. F. Scott (2006), Response to comment by P. F. Doyle on 'Camp Creek revisited: Streamflow changes following salvage harvesting in a medium-sized, snowmelt-dominated catchment', Can. Water Resour. J., 31, 135-138.

Moore, R. D., S. W. Fleming, B. Menounos, R. Wheate, A. Fountain, K. Stahl, K. Holm, and M. Jakob (2009), Glacier change in western North America: Implications for hydrology, geomorphic hazards and water quality, Hydrol. Processes, 23, 42-61, doi:10.1002/hyp.7162.

Regonda, S. K., B. Rajagopalan, M. Clark, and J. Pitlick (2005), Seasonal cycle shifts in hydroclimatology over the Western United States, J. Clim., $18,372-384$.

Rood, S. B., J. Pan, K. M. Gill, C. G. Franks, G. M. Samuelson, and A. Shepherd (2008), Declining summer flows of Rocky Mountain rivers: Changing seasonal hydrology and probable impacts on floodplain forests, J. Hydrol., 349, 397-410.

Schiefer, E., B. Menounos, and R. Wheate (2007), Recent volume loss of British Columbian glaciers, Canada, Geophys. Res. Lett., 34, L16503, doi:10.1029/2007GL030780.

Smith, L. C., T. M. Pavelsky, G. M. MacDonald, A. I. Shiklomanov, and R. B. Lammers (2007), Rising minimum daily flows in northern Eurasian rivers: A growing influence of groundwater in the high-latitude hydrologic cycle, J. Geophys. Res., 112, G04S47, doi:10.1029/2006JG000327. 
Stahl, K., and R. D. Moore (2006), Influence of watershed glacier coverage on summer streamflow in British Columbia, Canada, Water Resour. Res., 42, W06201, doi:10.1029/2006WR005022.

Stewart, I. T., D. R. Cayan, and M. D. Dettinger (2005), Changes toward earlier streamflow timing across western North America, J. Clim., 18, $1136-1155$.

St. Jacques, J.-M., and D. J. Sauchyn (2009), Increasing winter baseflow and mean annual streamflow from possible permafrost thawing in the Northwest Territories, Canada, Geophys. Res. Lett., 36, L01401, doi:10.1029/2008GL035822.

Theil, H. (1950), A rank-invariant method of linear and polynomial regression analysis, Indagationes Math., 12, 85-91.

von Storch, V. H. (1995), Misuses of statistical analysis in climate research, in Analysis of Climate Variability: Applications of Statistical Techniques, edited by V. H. von Storch and A. Navarra, pp. 11-26, Springer, Berlin.

Walvoord, M. A., and R. G. Striegl (2007), Increased groundwater to stream discharge from permafrost thawing in the Yukon River basin: Potential impacts on lateral export of carbon and nitrogen, Geophys. Res. Lett., 34, L12402, doi:10.1029/2007GL030216.

Whitfield, P. H., and A. J. Cannon (2000), Recent variations in climate and hydrology in Canada, Can. Water Resour. J., 25, 19-65.
Woo, M., and R. Thorne (2008), Analysis of cold season streamflow response to variability of climate in north-western North America, Hydrol. Res., 39, 257-265.

Woo, M., R. Thorne, and K. K. Szeto (2006), Reinterpretation of streamflow trends based on shifts in large-scale atmospheric circulation, Hydrol. Processes, 20, 3995-4003, doi:10.1002/hyp.6590.

Yue, S., P. Pilon, B. Phinney, and G. Cavadias (2002), The influence of autocorrelation on the ability to detect trend in hydrological series, Hydrol. Processes, 16, 1807-1829.

J. E. Burford and S. J. Déry, Environmental Science and Engineering Program, University of Northern British Columbia, 3333 University Way, Prince George, BC V2N 4Z9, Canada. (sdery@unbc.ca)

B. Menounos, Geography Program, University of Northern British Columbia, 3333 University Way, Prince George, BC V2N 4Z9, Canada.

R. D. Moore, Department of Geography, University of British Columbia, 1984 West Mall, Vancouver, BC V6T 1Z2, Canada.

K. Stahl, Department of Geosciences, University of Oslo, P.O. Box 1047, Oslo N-0316, Norway.

P. H. Whitfield, Environment Canada, Vancouver, BC V6C 3S5, Canada. 